\section{Climate smart Agriculture} Interventions in Selected Agricultural Growth Program-
II Districts of Harari Region and Dire Dawa Administration: Double Cropping Practices

\section{Ibsa Aliyi Usmane*, Abdulaziz Teha Umer, Nasir Siraj, Oromiya Magersa, Badaso Urgesa and Tashoma Urge}

Oromia Agricultural Research Institute, Fadis Agricultural Research Centre, P.O. Box 904, Harar, Ethiopia
Received: 29 October, 2020

Accepted: 18 January, 2021

Published: 19 January, 2021

*Corresponding author: Ibsa Aliyi Usmane, Oromia Agricultural Research Institute, Fadis Agricultural Research Centre, P.O. Box 904, Harar, Ethiopia, E-mail: ibsaaly2012@gmail.com

Keywords: Climate smart; Double cropping; Agricultural growth program-II https://www.peertechz.com

\section{Check for updates}

\begin{abstract}
Climate smart technology intervention in production and productivity enhancement of agriculture sector for small holder farmers' livelihood improvement is indispensable options. Taking this in consideration the double cropping practice research activity was undertaken with objectives of evaluate the productivity and profitability of double cropping practice technology under farmers condition, build farmers' knowledge and skill of different crop combination production and management practice and strengthen stakeholders linkages and collaboration among stakeholders. A total of fifteen (15) trial and follower farmers were selected and organized as form of Farmers Research Groups. Improved varieties of common bean (KATB-1 and Batu) and sorghum (Melkam and Local) were replicated on the plot of 10mx10m. The yield performance of the improved varieties (Batu, KATB-1, Melkam and Local sorghum) were 12.13, 13.43, 31.91 and 26.57qt/ha at Sofi, and 12.13, 13.66, 31.96 and 26.47qt/ha at Wahil, respectively. The double cropping practices preferred as it diversify the crop, more yield obtained, and shorter crop cycle, better to cope up the dry spell, efficient use of land, reduce risks of striga and reduce risk of bird infestation. Moreover, based on the obtained result, Batu, KATB-1 and Melkam combination preferred by farmers since they could able to harvest twice within single season. From knowledge point of view the mean score for knowledge test before intervention and after intervention is 4.47 and 7.37 respectively. The result of paired-sample t-test indicates a significant difference between the mean score for knowledge test before intervention and after intervention at $1 \%$ significant level. This implies an improvement of farmers' knowledge regarding the improved sorghum and Haricot-bean varieties as double cropping technologies due to technological intervention. Therefore, it is batter to be promoted and scale-up on wider area and reach large number of farmers.
\end{abstract}

\section{Introduction}

Rain-fed agricultural areas of East Africa are often food insecure due to rainfall variability and ongoing soil degradation that negatively impacts crop yields. Agricultural activities and consequently the livelihoods of people reliant on agriculture will be affected by changes in temperature and precipitation conditions in large parts of Sub-Saharan Africa [1]. Under climate change, many areas in Sub-Saharan Africa are likely to experience a decrease in the length of the growing season, while in some highland areas rainfall changes may lead to a prolongation of the growing season [1]. Agriculture in Africa remains one of the most vulnerable sectors to climate variability and change yet the sector faces various challenges including market system failures and trade barriers, unstable and ineffective socio-economic policies, poor information, infrastructural and financial accessibility, increasing population pressure and resources scarcity, unsustainable agronomic practices and environmental degradation. These challenges are further compounded by the effects of climate 
variability and change as the sector is mainly rain-fed and climate dependent [2].

According to CSA [3] in terms of adoption, most of the climate smart agriculture practices and technologies identified have low to medium on farm adoption rates, despite their potential benefits to adaptation, productivity increase and mitigation efforts. Many of the key barriers to widespread adoption include limited or no access to productive inputs (improved seeds and fertilizer), lack of access to credit, lack of adequate machinery and technology (e.g. row planters), low access to formal markets to sell produce, and limited extension service quality and access particularly in relation to climate smart agriculture. What so ever, mono-cropping of sorghum whether it is long or early maturing is their usual practice which aggravates the infestation of striga in case of susceptible varieties and has risk of crop failure in most cases due to erratic and unreliable rainfall [4].

Basically, the farming system should be revised in the cropping areas of Fedis, and similar dry lowlands of Hararghe. Since eight-month-cycle sorghum being rain-fed, is simply late maturing and too vulnerable to pests and dependent on rainfall patterns. A reorientation towards shorter cycle crops like early maturing sorghum, pulses and oil crops would help farmer's better cope with the climatic hazards of the area [4]. The degree of climate change impacts on agricultural production differs among crops and agricultural systems [5]. A study conducted by Melaku, et al. [6]at country level in Ethiopia has identified that the adoption rate of CSA practices is low. To support the facilitation for adoption, different key opportunities and challenges are identified and strategic measures were recommended to capitalize on the opportunities and remove the challenges. The study also indicated that there is a gap in research at local level regarding CSA (adoption status, opportunities and challenges) considering the biophysical, socio-economic and developmental context. These situations ask the need to conduct research at local context in order to strengthen the evidence based decisions 4 for adoption and dissemination of improved technologies across similar farming system [6]. Therefore, the farmers' choice of an adequate cropping system and crop cultivar, especially in precipitation-limited areas, might be an important adaptation strategy to changing climate conditions.

However, farmers in Fedis area are accustomed to sow the local varieties from end of March to the middle of April though they know the advantage of using improved sorghum varieties reduce risk of striga and yield. This is because farmers do not want to leave their land idle when the rain starts early in March/April until the right planting time of the early maturing striga resistant sorghum varieties [7]. Whereas, these improved varieties are sown after the local varieties from middle of June to the beginning of July and farmers who are adopting improved sorghum varieties are forced to leave their land idle to synchronize its maturity with long maturing sorghum varieties to reduce the high bird infestation prevailing in the area [5].
To alleviate this problem experiment have been done at Fedis on evaluation of suitable double cropping combination and mung-bean, haricot bean and cowpea were found to be economically and ecologically convenient in the area as preceding crops followed by early maturing sorghum in the area [5]. Therefore, farmers' participation in technology promotion is very important to be acceptance by the whole community of the areas through applying preceding and succeeding crops that conducted on station under the control of the researchers during 'Belg' and 'Meher' season as a result; this research activity was conducted with the following objectives.

\section{Objectives}

* To evaluate the productivity and profitability of double cropping practice technology under farmers' condition.

* To build farmers' knowledge and skill of different crop combination production and management practice

\# To strengthen stakeholders linkages and collaboration among stakeholders.

\section{Materials and methods}

This pre-extension demonstration of double cropping practices was conducted selected districts of Dire Dawa administration and Harari Region.

\section{Site and farmers selection}

Two kebeles Wahil from Dire Dawa Kile from Harari were selected while farmers were selected based on their interest, innovation he/she has, land provision for this pre-extension demonstration, interest in cost-sharing, willingness to share experiences for other farmers. The selected farmers were grouped in the form of Farmers Research Group (FRG) with the member of 15 ( 3 male trial farmers and 2 female trial farmers) and 10 farmers work with trial farmers Table 1.

\section{Technology evaluation and demonstration methods/ technique}

The evaluation and demonstration of the trials were conducted on farmers' fields to create awareness about the double cropping practices. The evaluation and demonstration of the trials were followed process demonstration approach by involving FRGs, development agents and experts at different growth stage of the crop. The activity was jointly monitored by FRGs, researchers, experts and development agents Table 2.

\section{Experimental design and implementation procedures}

Land preparation was done by tractor-powered and animal traction systems. The land was ploughed and smoothened to bring the soil to fine tilth and tie ridge was made in order to conserve moisture. The plots was laid out as per plan and plots was bunded lightly to prevent the entry of runoff water. Seeds of sorghum were drilled in the row of $75 \mathrm{~cm}$ between rows and $15-20 \mathrm{~cm}$ between plants and the spacing was the same for

Citation: Usmane IA, Umer AT, Siraj N, Magersa O, Urgesa B, et al. (2021) Climate smart Agriculture Interventions in Selected Agricultural Growth Program-II Districts of Harari Region and Dire Dawa Administration: Double Cropping Practices. J Agric Sc Food Technol 7(1): 014-019. 
Table 1: Summary of selected site and farmers with area coverage of the experiment.

\begin{tabular}{|c|c|c|c|}
\hline District & PAs & No. of trial and follower farmers & Area covered \\
\hline \multirow{2}{*}{$\begin{array}{c}\text { Dire Dawa } \\
\text { Sofi }\end{array}$} & Wahil & 7 & \multirow[b]{2}{*}{$10 \mathrm{~m} \times 10 \mathrm{~m}$ for each plots } \\
\hline & Kile & 8 & \\
\hline \multicolumn{2}{|c|}{ Total } & 15 & \\
\hline
\end{tabular}

Table 2: Treatments.

\begin{tabular}{|c|c|c|}
\hline No. & Preceding crop & Succeeding crop (sorghum) \\
\hline 1 & Haricot bean KATB-1 & Melkam \\
\hline 2 & Haricot bean var. Batu & Melkam \\
\hline 3 & Local sorghum & Local sorghum stays \\
\hline
\end{tabular}

sorghum during second sowing they were thinned to one plant per hill at spacing of $15-20 \mathrm{~cm}$.

Haricot bean was sown $40 \mathrm{~cm} \times 10 \mathrm{~cm}$ between rows and plants, respectively and for KATB-1 the spacing was $40 \mathrm{~cm} \mathrm{x}$ $5 \mathrm{~cm}$ between rows and plants, respectively. At first sowing, all plots were received a basal application of Di Ammonium Phosphate at the rate of $100 \mathrm{~kg} / \mathrm{ha}$. Four weeks after emergence for sorghum and KATB-1 N in the form of urea (46 kg N) was applied at the rate of $100 \mathrm{~kg} / \mathrm{ha}$ and for Haricot beans $23 \mathrm{~kg} \mathrm{~N}$ was applied at the rate of $50 \mathrm{~kg} / \mathrm{ha}$ when the soil moisture was enough. At the end of June the preceding crops was harvested and threshed after it is sun dried for one weak except the control since it takes 7 to 8 months to mature and grain yield per plot was recorded.

The succeeding crop and the control all sorghum were harvested on maturity. The stalks from net plot were cut close to ground level and later ears were separated. The ears were sun-dried, threshed and grain yield per plot was recorded after 7 days of sun drying.

\section{Data collection and analysis}

Qualitative data were collected through personal field observation, individual interview, Focus Group Discussion by using checklist and. Quantitative data were data collected by data sheet tools. Quantitative data was analyzed using simple descriptive statistics (Mean, Frequency and Percentage) while the qualitative data were analyzed using narrative explanation.

\section{Results and discussion}

\section{Training of farmers and other stalk holders}

Multidisciplinary research team; crop, extension and socio-economic research team and other stakeholders (Offices of Agriculture and Natural Resource) actively participated by sharing their experience and knowledge and journalists for publicity of the work done, Development agents, experts and farmers were participated on the training given on double cropping practices and management, post-harvest handling and marketing information Tables 3a,b.

Among the training participant stakeholders, $73.1 \%$ were farmers, from those farmers, $20 \%$ were female farmers' participants .
For those individuals, 70 leaflets and 40 small manuals on the technology that are organized in Afaan Oromoo and English languages were distributed. Most farmers showed high interest towards improved double cropping technology production because of better yield and earned income by selling it for different stakeholders (neighbors' farmers and NonGovernment Organizations). Generally, all farmers were very interested to have the technology for their future production.

\section{Agronomic and yield performance}

The following table describes the yield performances of the demonstrated Batu, KATB-1, Melkam and Local sorghum varieties across the study site. The yield performance of the improved varieties (Batu, KATB-1, Melkam and Local sorghum) were 12.13, 13.43, 31.91 and 26.57qt/ha at Sofi, and 12.13, 13.66, 31.96 and $26.47 \mathrm{qt} / \mathrm{ha}$ at Wahil, respectively this results agrees with findings of Wako RE and Usmane IA et al, 2020 [8] Table 4.

The average yield performance of Melkam is higher than local sorghum at Sofi and Wahil even though double harvest were obtained from the plot of Melkam but single harvest from the plot of local sorghum variety.

\section{Economic analysis Table 5.}

Table 3a: Number of participants on the training.

\begin{tabular}{|c|c|c|c|c|}
\hline No. & Participants & Male & Female & Total \\
\hline 1 & Farmers & 24 & 6 & 30 \\
\hline 2 & DAs & 3 & - & 3 \\
\hline 3 & District experts & 3 & 2 & 5 \\
\hline 4 & Journalists & 3 & 0 & 3 \\
\hline & Total & 33 & 8 & 41 \\
\hline
\end{tabular}

Source: Own computation 2018/19

Table 3b: Number of participants on the field day.

\begin{tabular}{|c|c|c|c|c|}
\hline No. & Participants & Male & Female & Total \\
\hline 1 & Farmers & 40 & 20 & 60 \\
\hline 2 & DAs & 5 & - & 5 \\
\hline 3 & District experts & 5 & - & 5 \\
\hline 4 & Journalists & 4 & 0 & 4 \\
\hline & Total & 54 & 20 & 74 \\
\hline
\end{tabular}

Table 4: Yield performance of improved varieties across districts.

\begin{tabular}{|c|c|c|c|c|c|c|}
\hline PA & Crop & Varieties & $\begin{array}{c}\text { Std. } \\
\text { Deviation }\end{array}$ & $\begin{array}{c}\text { Mean (qt/ } \\
\text { ha) }\end{array}$ & Maximum & Minimum \\
\hline \multirow{4}{*}{ Sofi } & \multirow{2}{*}{$\begin{array}{c}\text { Common } \\
\text { Bean }\end{array}$} & Batu & .931 & 12.13 & 13.00 & 11.00 \\
\hline & & KATB-1 & .940 & 13.43 & 14.50 & 12.00 \\
\hline & \multirow[b]{2}{*}{ Sorghum } & Melkam & 2.949 & 31.91 & 35.50 & 27.60 \\
\hline & & $\begin{array}{c}\text { Local } \\
\text { Sorghum }\end{array}$ & 1.683 & 26.57 & 29.00 & 24.10 \\
\hline \multirow{4}{*}{ Wahil } & \multirow{2}{*}{$\begin{array}{c}\text { Common } \\
\text { Bean }\end{array}$} & Batu & .931 & 12.13 & 13.00 & 11.00 \\
\hline & & KATB-1 & 1.015 & 13.66 & 15.70 & 12.50 \\
\hline & \multirow[b]{2}{*}{ Sorghum } & Melkam & 3.020 & 31.96 & 36.00 & 27.60 \\
\hline & & $\begin{array}{c}\text { Local } \\
\text { Sorghum }\end{array}$ & 1.812 & 26.47 & 29.00 & 24.00 \\
\hline & & & & & & 016 \\
\hline
\end{tabular}

Citation: Usmane IA, Umer AT, Siraj N, Magersa O, Urgesa B, et al. (2021) Climate smart Agriculture Interventions in Selected Agricultural Growth Program-II Districts of Harari Region and Dire Dawa Administration: Double Cropping Practices. J Agric Sc Food Technol 7(1): 014-019. DOI: https://dx.doi.org/10.17352/2455-815X.000082 
Table 5: Financial analysis for sorghum and common bean varieties across the districts.

\begin{tabular}{|c|c|c|c|c|c|c|c|c|c|}
\hline \multicolumn{10}{|c|}{ Financial analysis } \\
\hline \multicolumn{5}{|c|}{ Location: Sofi } & \multirow{3}{*}{$\begin{array}{l}\text { Location: Wahil } \\
\text { Parameters }\end{array}$} & & & & \\
\hline \multirow{2}{*}{ Parameters } & \multicolumn{4}{|c|}{ Varieties } & & \multicolumn{4}{|c|}{ Varieties } \\
\hline & Batu & KATB-1 & Melkam & Local & & Batu & KATB-1 & Melkam & Local \\
\hline Yield qt/ha(Y) & 12 & 13.5 & 32 & 29 & Yield qt/ha(Y) & 12.5 & 13.6 & 32 & 26.5 \\
\hline Price $(P)$ per quintal & 2000 & 2000 & 1000 & 1000 & Price(P)per quintal & 2000 & 2000 & 1000 & 1000 \\
\hline Total Revenue $(T R)=T R=Y * P$ & 24,000 & 27000 & 32000 & 29000 & Total Revenue $(T R)=T R=Y * P$ & 25000 & 27,200 & 32000 & 26,500 \\
\hline Variable costs & & & & & Variable costs & & & & \\
\hline Seed cost & 250 & 250 & 100 & 100 & Seed cost & 250 & 250 & 100 & 100 \\
\hline Fertilizer cost & 283 & 283 & 1701 & 1701 & Fertilizer cost & 283 & 283 & 1701 & 1701 \\
\hline Labor cost & 2,100 & 2,100 & 3000 & 3000 & Labor cost & 2,100 & 2,100 & 3000 & 3000 \\
\hline Total Variable costs(TVC) & 2,633 & 2,633 & 4,801 & 4,801 & Total Variable costs(TVC) & 2,633 & 2,633 & 4,801 & 4,801 \\
\hline Fixed costs & & & & & Fixed costs & & & & \\
\hline Cost of land & 2000 & 2000 & 2000 & 2000 & Cost of land & 2000 & 2000 & 2000 & 2000 \\
\hline Total fixed costs (TFC) & 2000 & 2000 & 2000 & 2000 & Total fixed costs (TFC) & 2000 & 2000 & 2000 & 2000 \\
\hline $\begin{array}{c}\text { Total cost } \\
(\mathrm{TC})=\mathrm{TVC}+\mathrm{TFC}\end{array}$ & 4,633 & 4,633 & 6,801 & 6,801 & Total cost $(\mathrm{TC})=\mathrm{TVC}+\mathrm{TFC}$ & 4,633 & 4,633 & 6,801 & 6,801 \\
\hline Gross Margin $(\mathrm{GM})=\mathrm{TR}-\mathrm{TVC}$ & 21,366 & 24,367 & 27,199 & 24,199 & Gross Margin $(\mathrm{GM})=\mathrm{TR}-\mathrm{TVC}$ & 22,367 & 24,567 & 27,199 & 21,699 \\
\hline Profit $=\mathrm{GM}-\mathrm{TFC}$ & 19,366 & 22,367 & 25,199 & 22,199 & Profit $=\mathrm{GM}-\mathrm{TFC}$ & 20,367 & 22,567 & 25,199 & 19,699 \\
\hline
\end{tabular}

\section{Farmers' Opinion/perception}

Farmers in the study area selected the best performing double cropping practices by using their own criteria. Farmers set these criteria after having know-how about the variety and using those criteria they could select the varieties at harvest time. The opinion of those farmers on varietal preference was collected from participants during variety demonstration. The major criteria used by farmers were diversify the crop, more yield obtained, shorter crop cycle, better to cope up the dry spell, efficient use of land, reduce risks of striga and reduce risk of bird infestation Tables 6-8.

\section{Knowledge test}

A simple knowledge test items were developed based on the contents of training and production package practices. Knowledge level of participant farmers regarding improved maize production technologies was measured before and after implementation. Score of 1 given for correct answers and 0 for incorrect answers. As presented by Table 9 below, the percentage of respondents for correct answers is increased after intervention, while the percentage for incorrect answers is decreased Tables 10.

\section{Discussion}

In Ethiopian context, climate smart agriculture practices (CSA) and technologies are being implemented within the framework of integrated watershed management, which incorporate a wide range of practices in crop and livestock production including agroforestry, crop rotation and intercropping as well as soil and water conservation measures such as soil/stone bunds, terracing, infiltration ditches, and tie ridges among others [9]. This research activity of double cropping is one of the strategies that implemented in study areas by domain of early matured Haricot bean varieties by succeeding early matured sorghum variety(Malkam) compared local sorghum variety. From the findings in Sofi district the preceding crop Haricot bean Batu yielded 12.13, KATB1 13.4
Table 6: Ranks of the varieties based on farmers' selection criteria.

\begin{tabular}{|c|c|c|c|}
\hline $\begin{array}{c}\text { Cropping } \\
\text { system }\end{array}$ & $\begin{array}{c}\text { Farmers } \\
\text { rank }\end{array}$ & Reasons \\
\hline $\begin{array}{c}\text { Double } \\
\text { Cropping }\end{array}$ & $1^{\text {st }}$ & $\begin{array}{r}\text { Diversify the crop ,more yield obtained, shorter crop cycle, } \\
\text { better to cope up the dry spell, efficient use of land, reduce } \\
\text { risks of striga and reduce risk of bird infestation }\end{array}$ \\
\hline $\begin{array}{c}\text { Single } \\
\text { Cropping }\end{array}$ & $2^{\text {nd }}$ & $\begin{array}{r}\text { Mono cropping ,less yield obtained ,longer crop cycle, } \\
\text { vulnerable to erratic rain fall, leave the land idle ,maximize the } \\
\text { risks of striga and maximize the risk of bird infestation }\end{array}$ \\
\hline
\end{tabular}

Table 7: Summary of Matrix Ranking of Farmers' Selection Criteria.

\begin{tabular}{|c|c|c|c|c|}
\hline S.no & Traits & Frequency & Percentage (\%) & Rank \\
\hline 1 & Diversify the Crop & 3 & 15 & $4^{\text {th }}$ \\
\hline 2 & Yield & 4 & 20 & $2^{\text {nd }}$ \\
\hline 3 & Efficient use of Land & 6 & 30 & $1^{\text {st }}$ \\
\hline 4 & Crop cycle & 1 & 5 & $6^{\text {th }}$ \\
\hline 5 & Cope up the dry spell & 4 & 20 & $3^{\text {rd }}$ \\
\hline 6 & Reduce the striga infestation & 2 & 10 & $5^{\text {th }}$ \\
\hline 7 & Reduce bird infestation & 0 & 0 & $7^{\text {th }}$ \\
\hline & Total & 20 & 100 & \\
\hline
\end{tabular}

Table 8: Direct Matrix Ranking.

\begin{tabular}{|l|l|l|l|l|l|}
\hline S.no & Traits & Double cropping & Single cropping & Total & Rank \\
\hline 1 & Diversify the Crop & 2 & 0 & 2 & 4 \\
\hline 2 & Yield & 2 & 1 & 3 & 2 \\
\hline 3 & Efficient use of Land & 2 & 2 & 4 & 1 \\
\hline 4 & Crop cycle & 1 & 0 & 1 & 6 \\
\hline 5 & Cope up the dry spell & 2 & 1 & 3 & 3 \\
\hline 6 & $\begin{array}{l}\text { Reduce the striga } \\
\text { infestation }\end{array}$ & 1 & 0 & 1 & 7 \\
\hline 7 & Reduce bird infestation & 1 & 1 & 2 & 5 \\
\hline Total & & 1 & 2 & & \\
\hline
\end{tabular}

following the succeeding crop sorghum variety (Malkam) yielded 31.91 where the comparison local variety yielded 2657 quintal/hectare simultaneously in Wahil cluster the Haricotbean variety Batu yielded 12.13q/h, KATB1 $13.43 \mathrm{q} / \mathrm{h}$ with 
Table 9: Knowledge test of double cropping practices.

\begin{tabular}{|c|c|c|c|c|c|}
\hline \multirow{3}{*}{ No } & \multirow{3}{*}{ Test Items } & \multicolumn{4}{|c|}{ Respondents' percentage } \\
\hline & & \multicolumn{2}{|c|}{ After } & \multicolumn{2}{|c|}{ Before } \\
\hline & & Correct & Incorrect & Correct & Incorrect \\
\hline 1 & Name at least one improved maize variety & 73.3 & 26.7 & 53.3 & 46.7 \\
\hline 2 & Seed rate of double crop required for one hectare? & 70 & 30 & 53.3 & 46.7 \\
\hline 3 & Fertilizer rate per hectare recommended for double crop? & 66.7 & 33.3 & 66.7 & 33.3 \\
\hline 4 & Recommended space between rows for maize & 66.7 & 33.3 & 40 & 60 \\
\hline 5 & Recommended space between Haricot-bean and sorghum plants & 66.7 & 33.3 & 40 & 60 \\
\hline 6 & Potential productivity (yield/ha) of the improved varieties & 53.3 & 46.7 & 26.7 & 73.3 \\
\hline 7 & $\begin{array}{c}\text { Haricot-bean and sorghum plant density (plant population) per hectare recommended for good } \\
\text { harvest }\end{array}$ & 30 & 70 & 0 & 100 \\
\hline 8 & Environmental yield losses due to particular biotic and abiotic constraints & 60 & 40 & 50 & 50 \\
\hline 9 & Potential yield losses due to environmental stresses & 56.7 & 43.3 & 33.3 & 66.7 \\
\hline 10 & $\begin{array}{l}\text { Actual yield/farmer yield/realized yield losses due to misuse of recommended agricultural } \\
\text { practices and environmental stress }\end{array}$ & 60 & 40 & 46.7 & 53.3 \\
\hline 11 & Economic yield losses due to post-harvest losses & 53.3 & 46.7 & 36.7 & 63.3 \\
\hline 12 & The recommended grain moisture content for double and single cropping harvest is $13 \%$ & 30 & 70 & 0 & 100 \\
\hline
\end{tabular}

Table 10: Results of paired-sample t-test for knowledge test.

\begin{tabular}{|l|l|l|l|}
\hline Score of knowledge test & Mean & St.Dev & T-value \\
\hline Total score after & 7.37 & 1.94 & $10.98^{\star \star \star}$ \\
\hline Total score before & 4.47 & 1.8 & \\
\hline Source: own computation, 2020;*** 1\% significance level &
\end{tabular}

the succeeding sorghum variety (malkam) yielded $31.96 \mathrm{q} / \mathrm{h}$ where it comparison local sorghum variety yielded $26.47 \mathrm{q} / \mathrm{h}$. This indicates that from equal land allocation the difference yield of sorghum showed $5 \mathrm{q} / \mathrm{h}$ in addition to Haricot-bean varieties yield $25.56 \mathrm{q} / \mathrm{h}$ which benefits farmers both in income generation and food access in their home expenditures.

Agriculture is the backbone of the Ethiopian economy [10]. This particular sector determines the growth of all other sectors and consequently, the whole national economy. On average, crop production makes up 60 percent of the sector's outputs, whereas livestock accounts for 27 percent and other areas contribute 13 percent of the total agricultural value added. The sector is dominated by small-scale farmers who practice rain-fed mixed farming by employing traditional technology, adopting a low input and low output production system. The land tilled by the Ethiopian small-scale farmer accounts for 95 percent of the total area under agricultural use and these farmers are responsible for more than 90 percent of the total agricultural output. Agriculture accounted for $49 \%$ of GDP, $85 \%$ of exports, and $85 \%$ of employment [11]. In addition to yield difference the income generation difference was calculated between double and single cropping practices, from former practices 66,932 Ethiopian birr was obtained while from last practices 22, 199 Ethiopian birr was obtained in Sofi district similarly in Wahil cluster from the double cropping practices 68,133 Ethiopian birr and from single cropping practices 19,699 Ethiopian birr was obtained. Accordingly, farmers in the study areas raised the challenges they have been facing due to climate change in which this research implementation in their study areas solved for them, as a result, ranked from first to seventh the double and single crop treatments comparison efficient use of land, yield cope up the dry spell, diversity of crop, reduction in bird infestation, crop cycle and reduce the striga infestation respectively through the direct matrix analysis.

From knowledge point of view the mean score for knowledge test before intervention and after intervention is 4.47 and 7.37 respectively. The result of paired-sample t-test indicates a significant difference between the mean score for knowledge test before intervention and after intervention at $1 \%$ significant level. This implies an improvement of farmers' knowledge regarding the improved sorghum and Haricot-bean varieties as double cropping technologies due to technological intervention.

\section{Conclusion and Recommendation}

Farmers in Harari and Dire Dawa have been practicing mono cropping of sorghum for a long period of time. The average land holding is fragmented and rainfall distribution is erratic. Such mono cropping does not ensure the production of adequate food for the family. This local sorghum variety is also susceptible to striga and affected by drought. Low yielder than improved sorghum varieties when the season is not good. It requires different planting season. Though some farmers are adopting improved sorghum varieties, still most of them are hesitating to delay planting even if the rain fall in March or April is good.

To ensure the food availability, access, stable and entitle and income generation at the household level using all season of rain fall is very important among which the double cropping is one option. In order to fulfill this intended purpose early maturing haricot bean and sorghum variety through preceding and succeeding practices compare with single cropping locally acting by farmers was implemented at Sofi and Wahil cluster in eastern part of Ethiopia which resulted with significant yield and income difference between double and single practices on farmers land. The yield difference of the double cropping resulted in 5q/h of sorghum variety (malkam) plus $25.56 \mathrm{q} / \mathrm{h}$ of two Haricot-bean varieties in which local yielded only 26.57q/h in Sofi district. Similarly in Wahil cluster the total yield obtained from sorghum $31.96 \mathrm{q} / \mathrm{h}$ plus $25.79 \mathrm{q} / \mathrm{h}$ in which local sorghum yielded only $26.47 \mathrm{q} / \mathrm{h}$. 
In addition to yield difference the income generation difference was calculated between double and single cropping practices, from former practices 66,932 Ethiopian birr was obtained while from last practices 22, 199 Ethiopian birr was obtained in Sofi district similarly in Wahil cluster from the double cropping practices 68,133 Ethiopian birr and from single cropping practices 19,699 Ethiopian birr was obtained. From this research findings since the double cropping practices more yielder and economical than single practices it is better to promote double cropping practices for further scaling up to reach large number of farmers through development practitioners, government climate change and natural resource conservation program, mass media and available and extension methods, and from knowledge point of view the mean score for knowledge test before intervention and after intervention is 4.47 and 7.37 respectively. The result of paired-sample t-test indicates a significant difference between the mean score for knowledge test before intervention and after intervention at $1 \%$ significant level. This implies an improvement of farmers' knowledge regarding the improved sorghum and Haricot-bean varieties as double cropping technologies due to technological intervention.

\section{References}

1. Muller C, Cramer W, Hare WL, Lotze-Campen H (2011) Climate change risks for African agriculture. Proceedings of the National Academy of Sciences of the United States of America 108: 4313-4315. Link: https://bit.ly/35QI8S7

2. Abraham B, Recha J, Morton J (2017) Smallholder Farmers'Adaptation to Climate Change and Determinants of their Adaptation Decisions in the Central Rift Valley of Ethiopia. Agriculture and Food Security (CCAFS), International Livestock Research Institute (ILRI).Nairobi 00100, Kenya. Link: https://bit.ly/3oWe8dQ
3. CSA (2017) Agricultural Sample Surveys 2017/2018 (2010 E.C.), Volume 1 Report on area \& production of major crops. Federal Democratic Republic of Ethiopia; Central Statistics Agency, Addis Ababa.

4. Tegene S, Atomsa B, Ayana A, Zewidie A, Biri A, et al. (2013) Efforts towards solving the effect of extreme striga hermontica infestation and shortage of rain on sorghum production in the lowlands of eastern Ethiopia: Open American Journal of Agricultural Research 1: 1-15. Link: https://bit.ly/3qHLRbJ

5. Abduselam F, Tana T, Abdulahi J, Nida H, Tadese T (2017) Evaluation of Double Cropping System for Sorghum Production at Fedis, Eastern Ethiopia: Journal of Plant Sciences 5: 75-81. Link: https://bit.ly/3bP4ICL

6. Jirata M, Sebastian G, Edward K (2016) Ethiopia Climate Smart Agriculture Scoping Study. FAO, Addis Ababa. Link: https://bit.ly/35P5nLf

7. Usmane IA, Teha A, Magersa O, Siraj N (2020) Early maturing sorghum technology promotion in selected Agricultural Growth Program-Il districts of Harari region and Dire Dawa City Administration rural areas. International Journal of Agricultural Science and Food Technology 6: 037-040. Link: https://bit.ly/3bNLesF

8. Wako RE, Usmane IA (2020) Evaluation of balanced fertilizer types on yield and yield components of sorghum and validation of soil fertility map based fertilizer recommendation. Journal of Food Science Nutrition Therapy 6: 026031. Link: https://bit.ly/2Ks96qE

9. FAO (2016) Ethiopia Climate-Smart Agriculture Scoping Study. Rome Food and Agriculture Organization of the United Nations. Link: https://bit.ly/3nVGPGq

10. Matousa P, Todob Y, Mojoc D (2013) Roles of extension and ethno-religious networks in acceptance of resource-conserving agriculture among Ethiopian farmers. International Journal of Agricultural Sustainability 11: 301-316. Link: https://bit.ly/3bOsHN5

11. UNDP (2016) Strengthening National Capacities to Enhance Agricultural Production and Productivity. United Nations Development Program.

\section{Discover a bigger Impact and Visibility of your article publication with}

\section{Peertechz Publications}

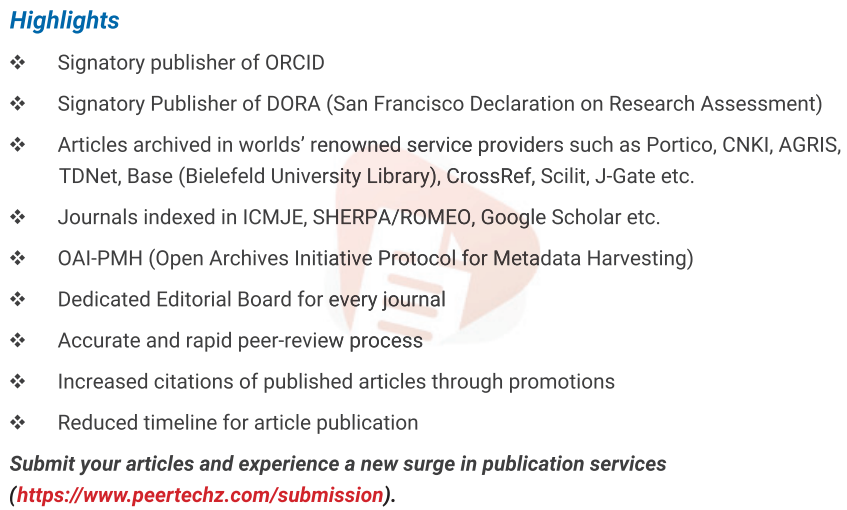

Copyright: @ 2021 Usmane IA, et al. This is an open-access article distributed under the terms of the Creative Commons Attribution License, which permits unrestricted use, distribution, and reproduction in any medium, provided the original author and source are credited.

Citation: Usmane IA, Umer AT, Siraj N, Magersa O, Urgesa B, et al. (2021) Climate smart Agriculture Interventions in Selected Agricultural Growth Program-II Districts of Harari Region and Dire Dawa Administration: Double Cropping Practices. J Agric Sc Food Technol 7(1): 014-019. 